\title{
Effects of droplet size and spray interval on root-to-shoot ratio, photosynthesis efficiency, and nutritional quality of aeroponically grown butterhead lettuce
}

\author{
Mazhar Hussain Tunio, Jianmin Gao*, Waqar Ahmed Qureshi, Sher Ali Sheikh, Jiedong Chen, \\ Farman Ali Chandio, Imran Ali Lakhiar, Kashif Ali Solangi \\ (School of Agricultural Engineering, Jiangsu University, Zhenjiang 212013, Jiangsu, China)
}

\begin{abstract}
The proper selection of the atomizer (droplet size) and nutrient solution spray interval is one of the most important factors to be investigated in aeroponics systems for sustainable agriculture. The aim of this study was to research the effects of four aeroponics atomizing nozzles (one air-assisted; $\mathrm{A}_{1}$, two air-less; $\mathrm{A}_{2}$ and $\mathrm{A}_{3}$, and one ultrasonic fogger; $\mathrm{A}_{4}$ ) with droplet sizes of $11.24 \mu \mathrm{m}, 26.35 \mu \mathrm{m}, 17.38 \mu \mathrm{m}$, and $4.89 \mu \mathrm{m}$, respectively, four spray intervals $\left(15 \mathrm{~min}\left(\mathrm{I}_{1}\right), 30 \min \left(\mathrm{I}_{2}\right), 45 \mathrm{~min}\left(\mathrm{I}_{3}\right)\right.$ and $60 \mathrm{~min}\left(\mathrm{I}_{4}\right)$ ) at a $5 \mathrm{~min}$ of constant spray time by atomizing the Hoagland's nutrient solution on growth, root-to-shoot ratio, photosynthesis characteristics, pigments, and nutritional quality of the aeroponically grown lettuce. The experimental results demonstrated that in $\mathrm{A}_{1}$ atomizer and $\mathrm{I}_{2}$ interval, the growth, photosynthesis efficiency, chlorophyll, carotenoids, and nutritional values of the lettuce were significantly higher compared to that grown in $\mathrm{A}_{2}$ and $\mathrm{A}_{3}$ atomizers at all spray intervals. The shoot developments were more constrained than root, prominent to the alteration of root-to-shoot ratio (fresh and dry) in the influence of different droplet sizes and spray intervals. Moreover, the plants did not grow well in $\mathrm{A}_{4}$ atomizer associated with proposed spray intervals. The results disclosed that there was an obvious interaction between droplet sizes (atomizers) and spray intervals for growth, the ratio of root to shoot, photosynthesis efficiency, pigments, and nutritional quality of the aeroponically grown lettuce. This research study increases the awareness of the proper droplet size (atomizer) and the regulation of nutrient solution spray interval for leafy vegetables grown in an aeroponics system.
\end{abstract}

Keywords: aeroponics system, atomizers, droplet sizes, photosynthesis efficiency, chlorophyll contents, quality of lettuce DOI: $10.25165 /$ j.ijabe.20221501.6725

Citation: Tunio M H, Gao J M, Qureshi W A, Sheikh S A, Chen J D, Chandio F A, et al. Effects of droplet size and spray interval on root-to-shoot ratio, photosynthesis efficiency, and nutritional quality of aeroponically grown butterhead lettuce. Int J Agric \& Biol Eng, 2022; 15(1): 79-88.

\section{Introduction}

Food security has become an increasingly important issue worldwide. Demographers predicted that the population will dramatically increase in the coming decades ${ }^{[1]}$. At the same time, land specialists such as agronomists, ecologists, and geologists warned that the shortage of arable land is getting worse $\mathrm{e}^{[2,3]}$. It was found that in recent decades additional traditional farmland will be needed to feed a large population. Only $80 \%$ of the Earth's arable land is suitable for farming now. Roughly $15 \%$ of this land has been rendered unusable for farming due to poor management and unpredicted climate change ${ }^{[4]}$. For these reasons, food demand

\section{Received date: 2021-04-28 Accepted date: 2021-06-22}

Biographies: Mazhar Hussain Tunio, PhD candidate, research interest: soilless culture and droplet size. Email: mazharhussaintunio@sau.edu.pk; Waqar Ahmed Qureshi, PhD candidate, research interest: sprinkler irrigation system, waqar128ahmad@gmail.com; Sher Ali Sheikh, PhD candidate, research interest: agriculture machinery, Email: sashaikh@sau.edu.pk; Jiedong Chen, Post-graduate candidate, research interest: aeroponics systems, Email: 2221816033@ujs.edu.cn; Farman Ali Chandio, Post-PhD fellowship, research interest: agriculture Machinery, Email: farman@ujs.edu.cn; Imran Ali Lakhiar, PhD candidate, research interest: soilless culture and droplet size, Email: 5103160321@stmail.ujs.edu.cn; Kashif Ali Solangi, PhD candidate, research interest: soil salinity control, Email: 5103180312@stmail.ujs.edu.cn. *Corresponding Author. Jianmin Gao, Professor, research interest: soil and fog tilling. No.301, Xuefu Road, Zhenjiang 212013, Jiangsu, China. Tel: +86-13655282069, Email: gaojianminujs@163.com. could exponentially surpass supply, leading to global famine. Another leading issue is that the crops are completely decedent on weather ${ }^{[4]}$. To solve the problems, new farming methods have been searched, one of them being soilless culture. Soilless cultivation has many advantages, such as more efficient regulation of nutrients; efficient use of water and fertilizers; high-density cultivation; higher yield per unit area; year-round production; higher quality; easy harvesting process; and negligible contamination from pollutants, pests, and pathogens ${ }^{[5-8]}$. Soilless culture, including hydroponics, aquaponics, and aeroponics, is one of the most innovative agricultural strategies that can produce more food from fewer resources ${ }^{[6,8-12]}$.

With regard to the use of soilless cultivation for vegetable production in developing countries, aeroponics cultivation is the most appropriate technique of soilless cultivation, as it requires less equipment and is inexpensive, locally available, and easy to operate $^{[7]}$. International Society for Soilless Cultivation defined aeroponics plant cultivation as "a system in which the root is continuously or discontinuously exposed to the condition of fine drop saturation (a mist) of nutrient solution" ${ }^{\text {"[13] }}$. Plant roots are developed in a two-phase root environment (liquid and air). Aeroponic culture does not involve the antagonism between water and air in the root environment. Continuous contact with oxygen stimulates metabolic processes, which has positive effects on the development of roots and nutrient uptake ${ }^{[14]}$. Advantageous effects of the aeroponics culture have been found for tomato, 
cucumber, and strawberry ${ }^{[15-17]}$, leafy vegetables ${ }^{[18-20]}$, potato ${ }^{[11,21,22]}$, herbs and medicinal plants ${ }^{[23,24]}$, chrysanthemum ${ }^{[25]}$, anthurium ${ }^{[26]}$, Eustoma, lisianthus and zantedeschia ${ }^{[23]}$, Ficus benjamina L. ${ }^{[22]}$, Acacia mangium Willd. ${ }^{[27]}$, cranberry ${ }^{[28]}$, and lettuce ${ }^{[7,29]}$.

In addition, in an aeroponic system, plant roots receive a direct nutrient solution supply sprayed from the atomizers with different droplet sizes ${ }^{[30,31]}$. A study by Tibbitts et al. ${ }^{[32]}$ reported that with continuous nutrient atomization, plants become dependent on the constant spray, and any interruption of the spray causes loss of plant life. Continuous nutrient atomization can also contribute to fungal and bacterial growth on or near the plants. Moreover, an accurate interval and duration for nutrient atomization scheduling can produce healthier and more natural plant roots than constant atomization. The interval and duration of nutrient atomization help the plants to thrive longer at lower moisture levels and reduce pathogen infection ${ }^{[33]}$.

Lettuce (Lactuca sativa L.) is one of the most world popular vegetables used for fresh consumption as salad ${ }^{[2,34-37]}$. Nowadays, it has become the interest of many researchers for indoor experiments due to its high nutrition value and mineral contents ${ }^{[3]}$. Therefore, the lettuce was also selected as a test crop. Given the above, the aeroponic atomizer (droplet size), spray time, and interval can be considered as the main parameters influencing the cultivated plant growth $^{[29,30]}$. However, in our literature review, we found limited research studies regarding the effects of aeroponic atomizer and spray interval on the photosynthesis characteristics and pigments of any specific leafy plant. It was hypothesized that droplet size and spray intervals may have an impact on growth, root-to-shoot ratio, photosynthesis efficiency, and nutritional quality of lettuce and this data may be helpful for the accuracy of inventories. Thus, the object of this study was to determine the effect of different droplet sizes (atomizers) and spray intervals on root-to-shoot ratio, photosynthesis efficiency, and nutritional quality of aeroponically grown lettuce.

\section{Materials and methods}

\subsection{Experimental site and climate conditions}

The experiment was carried out between November-December 2019 at Jiangsu University, China, in a Venlo-type glasshouse equipped with outside and inside shade nets, fans, pad, and spray system. Figure 1 shows the maximum and minimum temperature along with relative humidity during the study period that was recorded daily at $1 \mathrm{~min}$ interval with an automatic weather station (Hobo U12-012, Onset Computer Corp.) located in the center of the aeroponic systems.

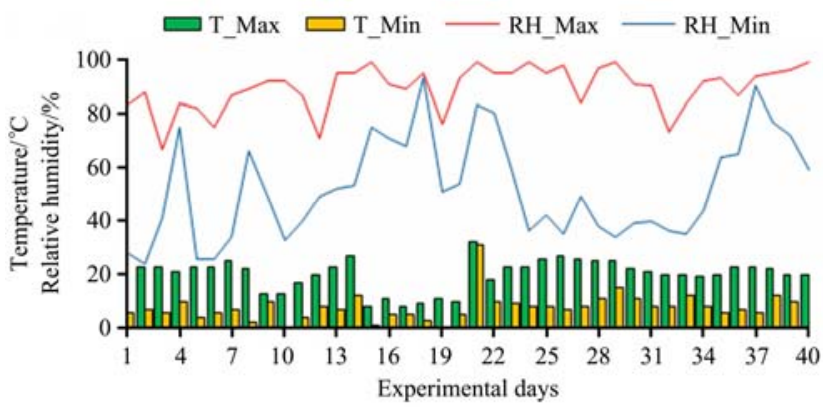

Note: T: Temperature; RH: Relative humidity; Max: Maximum; Min: Minimum

Figure 1 Daily maximum and minimum temperature and relative humidity inside the greenhouse

\subsection{Design of the aeroponic system}

The experiment was conducted with the existing aeroponic system previously designed by our research team ${ }^{[30]}$. This system consisted of a steel frame and high-density polyethylene (HDPE) containers with styrofoam lids and a volumetric capacity of $140 \mathrm{~L}$ (Figure 2a). The systems were designed and manufactured with the four types of spray atomizers (an air-assisted high-pressure atomizer (Figure 2b), two airless atomizers (Figures 2c and 2d), and an ultrasonic fogger (Figure 2e) with different droplet diameters. The air-assisted aeroponic system was designed with three paths: an air inlet path, a water inlet path, and a water outlet path. The systems with airless atomizers were designed with two paths: a water inlet path and water to atomize the liquid. Therefore, in this experiment, the water inlet system was composed of a pressure pump (model PLD-1206, Shijiazhuang City Prandy Electromechanical Equipment Co., Ltd., China), while the air inlet system was composed of an air compressor (OTS-550, Taizhou Outstanding Industry and Trade Co., Ltd, Taizhou, China), as shown in Figure 2a. Furthermore, the ultrasonic aeroponic system consisted of an atomizing chamber, an ultrasonic fogger, a nutrient solution pipeline, a reflux pipeline, a nutrient solution collector pump, a fluid infusion measuring pump, an axial flow fan, and a cultivation box. The fogger is a metal-plated device used to produce ultrasonic vibrations. Normally, the ultrasonic foggers were one to four inches in the nutrient solution within the growth chamber. The flexible polyethylene water and air supply lines were connected to the atomization nozzles through the pressure pump and the air compressor. In addition, the flow of the atomizing nutrient solution was released at different intervals by a digital timer (Figure 2a).
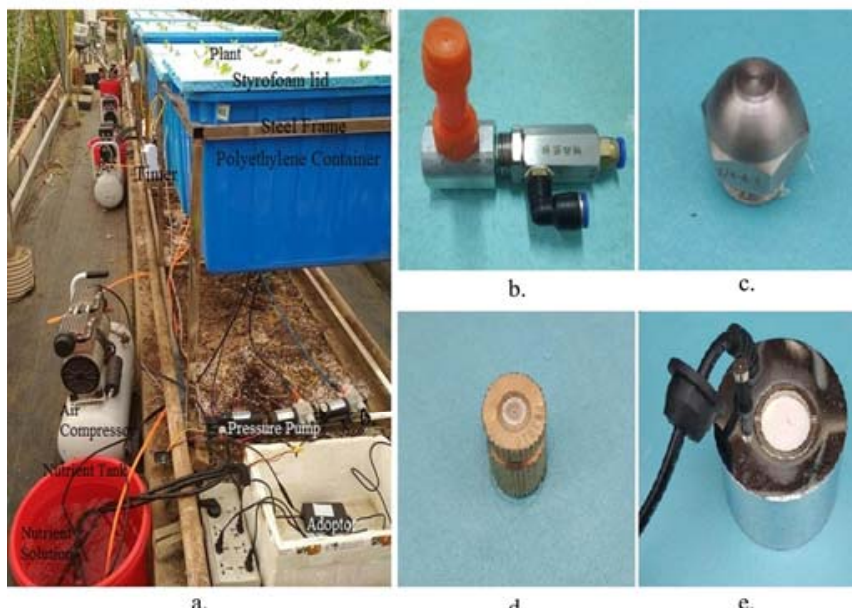

Note: a. Experimental setup b. Air-assisted atomizer $\quad c \&$ d. Air-less atomizer e. Piezoelectric ultrasonic fogger

Figure 2 Composition of the experiment system of this study

\subsection{Experimental arrangement}

The experiments were conducted to study the effects of droplet sizes and spray intervals on growth, root-to-shoot ratio, photosynthesis characteristics, pigments, and nutritional quality of aeroponically grown lettuce. Therefore, four atomizers and four nutrient solution spray intervals were evaluated in a factorial $(4 \times 4)$ randomized complete block design. The air-assisted atomizer (Figure 2b) was designed and manufactured by the authors' research team ${ }^{[38]}$, and the rest of the atomizers were purchased from the local market near the experimental site.

For the determination of the droplet size of the selected atomizers, a laser particle size analyzer (Winner318B, Jinan Winner Particle Instruments Stock Co., Ltd., Jinan, China), a computer, an air compressor, and a pressure pump were used. 
The working pressures of the air compressor, water pump, and water flow rate for the air-assisted atomizer were $0.4 \mathrm{MPa}, 0.2 \mathrm{MPa}$, and $4 \mathrm{~L} / \mathrm{min}$, respectively. A pump pressure of $0.2 \mathrm{MPa}$ and a water flow rate of $1 \mathrm{~L} / \mathrm{min}$ were stable for each airless atomizer, and the flow rate of each ultrasonic fogger was $1 \mathrm{~L} / \mathrm{min}$. More importantly, the flow rates and pressures were kept constant for the air compressor and water pump throughout the cultivation period. The detail of the experimental setup is presented in Table 1.

Table 1 Treatments used in the experiment for the lettuce in an aeroponic system

\begin{tabular}{llccc}
\hline $\mathrm{T}$ & \multicolumn{1}{c}{ Atomizers } & $S_{i} / \mathrm{min}$ & $S_{t} / \mathrm{min}$ & $D_{\text {av }} / \mu \mathrm{m}$ \\
\hline $\mathrm{A}_{1} \mathrm{I}_{1}$ & Air-assisted & 15 & 5 & 11.24 \\
$\mathrm{~A}_{2} \mathrm{I}_{1}$ & Airless & 15 & 5 & 26.35 \\
$\mathrm{~A}_{3} \mathrm{I}_{1}$ & Airless & 15 & 5 & 17.38 \\
$\mathrm{~A}_{4} \mathrm{I}_{1}$ & Ultrasonic fogger & 15 & 5 & 4.89 \\
$\mathrm{~A}_{1} \mathrm{I}_{2}$ & Air-assisted & 30 & 5 & 11.24 \\
$\mathrm{~A}_{2} \mathrm{I}_{2}$ & Airless & 30 & 5 & 26.35 \\
$\mathrm{~A}_{3} \mathrm{I}_{2}$ & Airless & 30 & 5 & 17.38 \\
$\mathrm{~A}_{4} \mathrm{I}_{2}$ & Ultrasonic fogger & 30 & 5 & 4.89 \\
$\mathrm{~A}_{1} \mathrm{I}_{3}$ & Air-assisted & 45 & 5 & 11.24 \\
$\mathrm{~A}_{2} \mathrm{I}_{3}$ & Airless & 45 & 5 & 26.35 \\
$\mathrm{~A}_{3} \mathrm{I}_{3}$ & Airless & 45 & 5 & 17.38 \\
$\mathrm{~A}_{4} \mathrm{I}_{3}$ & Ultrasonic fogger & 45 & 5 & 4.89 \\
$\mathrm{~A}_{1} \mathrm{I}_{4}$ & Air-assisted & 60 & 5 & 11.24 \\
$\mathrm{~A}_{2} \mathrm{I}_{4}$ & Airless & 60 & 5 & 26.35 \\
$\mathrm{~A}_{3} \mathrm{I}_{4}$ & Airless & 60 & 5 & 17.38 \\
$\mathrm{~A}_{4} \mathrm{I}_{4}$ & Ultrasonic fogger & 60 & 5 & 4.89 \\
\hline
\end{tabular}

Note: $T$ : treatments; $S_{i}$ : Spray interval; $S_{t}$ : Spray time, $D_{\mathrm{av}}$ : Average droplet size.

\subsection{Plant material and nutrient solution}

Lettuce (Lactuca sativa L.) seeds were obtained from Nanjing Ideal Agricultural Science and Technology Co., Ltd. Jiangsu, P.R. China. The seeds were planted in polystyrene trays (EPS) with 72 cells containing equal quantities of perlite material with a chemical composition of $\mathrm{SiO}, \mathrm{AlO}, \mathrm{K}_{2} \mathrm{O}, \mathrm{Na}_{2} \mathrm{O}, \mathrm{Fe}_{2} \mathrm{O}$, and $\mathrm{H}_{2} \mathrm{O}$. To have good plant growth for initial seedling, all cultural practices were continued. Moreover, during seeding, natural sunlight was provided with an intensity of approximately $800-900 \mu \mathrm{mol} / \mathrm{m}^{2} \cdot \mathrm{s}$. The seedling transplantation to the aeroponics system was carried out after $15 \mathrm{~d}$ of sowing. Each aeroponic box contained 12 plants at a spacing of $14 \mathrm{~cm} \times 16 \mathrm{~cm}$. From the two-true-leaf stage, the seedlings were regularly hand-watered with half-strength Hoagland solution for three days to avoid unnecessary stress on the plants. Additionally, the Hoagland's nutrient solution was sprayed with four different atomizers at $15 \mathrm{~min}, 30 \mathrm{~min}, 45 \mathrm{~min}$, and $60 \mathrm{~min}$ of spray intervals throughout the experiment. The chemical compositions of micro and macronutrient for leafy vegetables in soilless culture are represented in Table 2. The $\mathrm{pH}$ and EC of the nutrient solution were measured every day from each treatment. A fresh nutrient solution with maintained $\mathrm{pH}$ (5.8-6.0) and EC (1.6-2.2 $\mathrm{dS} / \mathrm{m})$ value was replaced with recycled one on the fifth day during the entire experiment of $40 \mathrm{~d}$ after transplant $(\mathrm{DAT})^{[39,40]}$. The equipment for measurement of $\mathrm{pH}$ and $\mathrm{EC}$ were used as reported by our research team Lakhiar et al. ${ }^{[8]}$

Table 2 Nutrient composition

\begin{tabular}{lccc}
\hline \multicolumn{1}{c}{ Composition } & $\begin{array}{c}\text { Concentration } \\
/ \mathrm{mg} \cdot \mathrm{L}^{-1}\end{array}$ & Composition & $\begin{array}{c}\text { Concentration } \\
/ \mathrm{mg} \cdot \mathrm{L}^{-1}\end{array}$ \\
\hline $\mathrm{Ca}\left(\mathrm{NO}_{3}\right)_{2} \cdot 4 \mathrm{H}_{2} \mathrm{O}$ & 945 & $\mathrm{H}_{3} \mathrm{BO}_{3}$ & 2.86 \\
$\mathrm{KNO}_{3}$ & 607 & $\mathrm{MnSO}_{4} \cdot 4 \mathrm{H}_{2} \mathrm{O}$ & 2.13 \\
$\mathrm{NH}_{4} \mathrm{H}_{2} \mathrm{PO}_{4}$ & 115 & $\mathrm{ZnSO}_{4} \cdot 7 \mathrm{H}_{2} \mathrm{O}$ & 0.22 \\
$\mathrm{MgSO}_{4} \cdot 7 \mathrm{H}_{2} \mathrm{O}$ & 493 & $\mathrm{CuSO}_{4} \cdot 5 \mathrm{H}_{2} \mathrm{O}$ & 0.08 \\
$\mathrm{FeEDTA}$ & 28 & $\left(\mathrm{NH}_{4}\right)_{6} \mathrm{Mo}_{7} \mathrm{O}_{24} \cdot 4 \mathrm{H}_{2} \mathrm{O}$ & 0.02 \\
\hline \multicolumn{4}{c}{$5.8-6.0$} \\
\multicolumn{4}{c}{$\mathrm{pH}$} \\
\multicolumn{3}{c}{$\mathrm{EC} / \mathrm{dS} \cdot \mathrm{m}^{-1}$} & \multicolumn{2}{c}{$1.6-2.2$} \\
\hline
\end{tabular}

\subsection{Vegetative growth and biomass analysis}

After 40 DAT, four plants separately from each treatment were randomly selected for the measurement of average root length (RL), shoot length (SL), leaf area (LA), shoot and root weight of aeroponically cultivated lettuce. The average RL $(\mathrm{cm})$ and SL $(\mathrm{cm})$ were measured using a measuring tape scale. The leaf area $\left(\mathrm{cm}^{2}\right)$ was measured with a laser leaf area meter (CI-203, CID BioScience, Inc., Camas, Wash.). More importantly, for biomass analysis, the same plants were washed with tap water, and the free surface moisture was immediately removed using a soft paper towel. The fresh weight of roots (RFW), and shoots (SFW) was measured on a scale accurate to $0.0001 \mathrm{~g}$. Furthermore, the root and shoot samples were put into the envelopes and oven-dried at $85^{\circ} \mathrm{C}$ for $72 \mathrm{~h}$, and the same procedure was applied to measure the dry weight of shoots (SDW), and roots (RDW). The root-to-shoot ratio was calculated as the root weight/shoot weight (fresh and dried ${ }^{[2,40-42]}$. Figure 3 shows the shoot and root growth of aeroponically grown lettuce during the experiment.
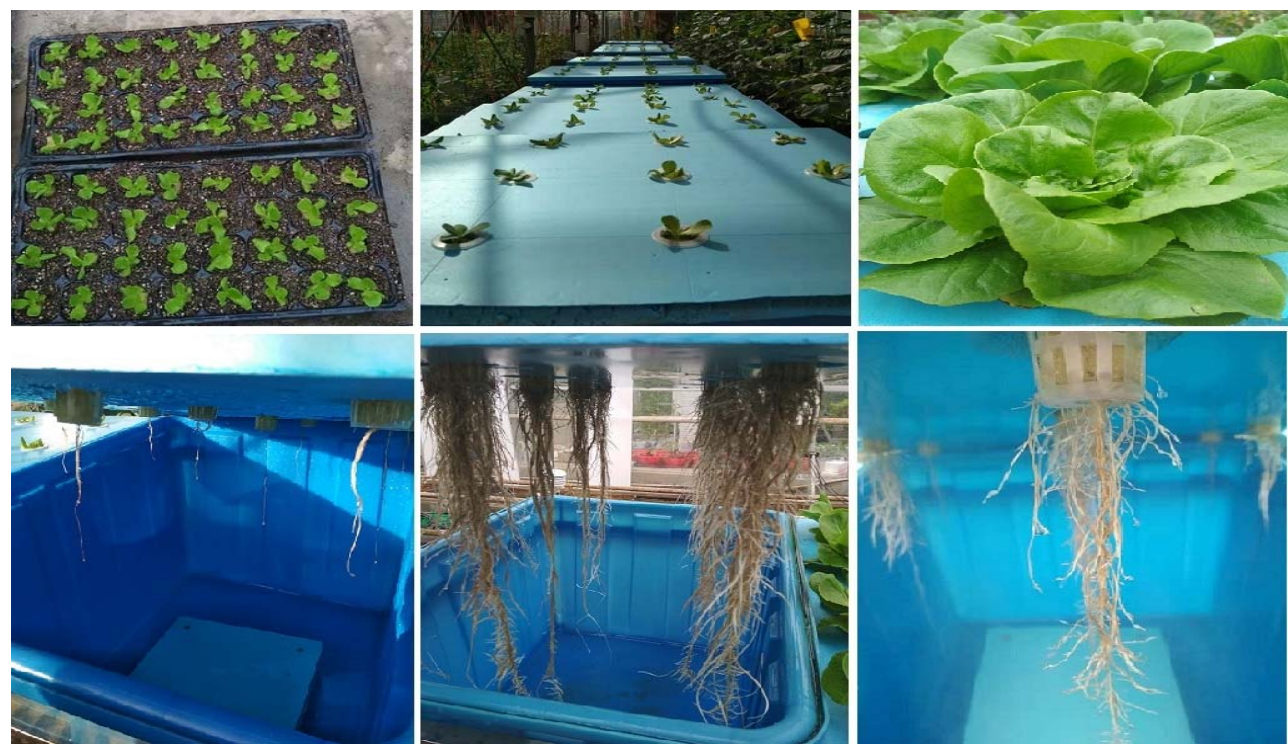

Figure 3 Growth for shoot and root of lettuce in aeroponic systems 


\subsection{Photosynthesis characteristics and pigment content}

\section{determination}

On the 40th day after transplant (DAT) in the aeroponic system, the lettuce finished exponential growth, and we conducted the measurements of net photosynthesis rate (Pn), leaf stomatal conductance $(\mathrm{Gs})$, leaf intercellular $\mathrm{CO}_{2}$ concentration, $(\mathrm{Ci})$, and transpiration rate (Eleaf) of the fourth leaf using a portable LI-6400XT photosynthesis instrument (Li-Cor 6400-18, Lincoln, $\mathrm{NE}, \mathrm{USA})^{[43]}$. It is, therefore, randomly selected four plants from each treatment were selected and five repeated measurements were taken from fully expanded leaves of the same four plants for Pn, Gs, $\mathrm{Ci}$, Eleaf, chlorophyll, and carotenoids. The measurements were taken place on the fully shining day from 10:00 a.m. to 1:30 p.m. Moreover, the values of atmospheric pressure $99.9 \mathrm{kPa}$, and photosynthetic active radiation (PAR) of $800 \mu \mathrm{mol} / \mathrm{m}^{2} \cdot \mathrm{s}$ were set in the photosynthesis machine. The optical density was measured with a UV-1200 spectrophotometer (SP-75, Shanghai spectrum instruments Co., Ltd., China) at $663 \mathrm{~nm}$ (OD663) for chlorophyll a, $645 \mathrm{~nm}$ (OD645) for chlorophyll b and $470 \mathrm{~nm}$ $(\mathrm{A} 470)^{[44,45]}$. More importantly, chlorophyll a (Ca), chlorophyll $\mathrm{b}(\mathrm{Cb})$, and carotenoids $\left(\mathrm{Cx}^{+}\right)$were calculated using the following equations $^{[46]}$ :

$$
\begin{aligned}
& \mathrm{Ca}=12.21 \mathrm{~A} 663-281 \mathrm{~A} 646 \\
& \mathrm{Cb}=20.13 \mathrm{~A} 663-5.03 \mathrm{~A} 646 \\
& \mathrm{Cx}^{+}=\frac{1000 \mathrm{~A} 470-3.27 \mathrm{Ca}-104 \mathrm{Cb}}{229}
\end{aligned}
$$

\subsection{Nutritional quality analysis}

For the determination of quality analysis, four samples from each treatment were lyophilized with liquid nitrogen and frozen at $-80^{\circ} \mathrm{C}$ for assay of vitamin $\mathrm{C}$, nitrate, soluble sugar and soluble protein. The 2, 6-dichloroindophenol dye (AOAC 2000) was used to determine vitamin $\mathrm{C}$ levels ${ }^{[47]}$. Moreover, according to previous studies, a chromatograph (ICS 90 DIONEX, US) was used to detect the nitrate level ${ }^{[41,48]}$. The soluble protein content in lettuce leaves was calculated using the Coomassie brilliant blue G-250 dye method ${ }^{[49]}$. Finally, anthronesulfuric acid colorimetry was used to examine the soluble sugar content in the lettuce leaves ${ }^{[50]}$.

\subsection{Statistical analysis}

The test results are reported as the mean \pm standard error (SE) values. The two-way variance of analyses (ANOVA) with student post hoc comparisons was performed to test for main and interaction of droplet sizes (atomizers) and spray intervals for all variables of growth, photosynthesis efficiency, pigments, and nutritional quality of lettuce. All statistical analyses were performed using SPSS Statistics and Microsoft Excel 2016.

\section{Results and discussion}

The hypothesis of the present study was confirmed, it was observed that shoot and root growth, fresh and dry weight, root-to-shoot ratio, photosynthesis efficiency, pigments, and nutritional quality of lettuce crop presented a significant influence in air-assisted $\left(A_{1}\right)$, air-less atomizers $\left(A_{2}\right.$ and $\left.A_{3}\right)$ at 15 min, $30 \mathrm{~min}, 45 \mathrm{~min}$, and $60 \mathrm{~min}$ of spray intervals with $5 \mathrm{~min}$ of constant spray time.

\subsection{Droplet size distribution}

The percentage of droplets with a cumulative mean diameter for the four different atomizers working at the same pressure is listed in Table 3. Diameters $d_{10}, d_{25}, d_{50}, d_{75}$, and $d_{90}$ represent the diameters corresponding to cumulative droplet frequencies at $10 \%$,
$25 \%, 50 \%, 75 \%$ and $90 \%$, respectively. The average maximum droplet size diameter $\left(D_{\text {avg }}\right)$ was calculated in airless atomizer $\left(\mathrm{A}_{2}\right)$ followed by $A_{3}, A_{1}$, and $A_{4}$ atomizers.

Table 3 Droplet diameters $(\mu \mathrm{m})$ of different atomizers

\begin{tabular}{ccccccccc}
\hline Atomizers & $\begin{array}{c}\text { Pump } \\
\text { pressure/MPa }\end{array}$ & $\begin{array}{c}\text { Flow rate } \\
/ \mathrm{L} \cdot \mathrm{m}^{-1}\end{array}$ & $d_{10}$ & $d_{25}$ & $d_{50}$ & $d_{75}$ & $d_{90}$ & $D_{\text {avg. }}$ \\
\hline $\mathrm{A}_{1}$ & 0.2 & 4 & 3.29 & 5.73 & 9.87 & 15.09 & 22.2 & 11.24 \\
$\mathrm{~A}_{2}$ & 0.2 & 1 & 6.41 & 13.74 & 21.72 & 37.4 & 52.5 & 26.35 \\
$\mathrm{~A}_{3}$ & 0.2 & 1 & 3.32 & 7.67 & 15.24 & 24.98 & 35.8 & 17.38 \\
$\mathrm{~A}_{4}$ & 0.2 & 1 & 0.21 & 1.49 & 3.08 & 6.15 & 13.14 & 4.89 \\
\hline
\end{tabular}

3.2 Vegetative growth and biomass analyses

3.2.1 Measurement of root length (RL), shoot length (SL), and leaf area (LA)

The experimental results of average RL, SL, and LA are presented in Figure 4. It can be seen from the figure, there is noticeable difference between treatments. The ANOVA findings showed significant effects of atomizers and nutrient solution spray intervals on root length, shoot length, and leaf area. It was revealed that the $A_{1}$ atomizer and the $I_{3}$ spray interval presented the maximum average root length $(62.94 \mathrm{~cm})$ in lettuce plants compared to the $A_{2}, A_{3}$, and $A_{4}$ atomizers with $15 \mathrm{~min}, 30 \mathrm{~min}$, $45 \mathrm{~min}$, and $60 \mathrm{~min}$ spray intervals. However, the minimum root length $(11.25 \mathrm{~cm})$ was observed in ultrasonic fogger $\left(\mathrm{A}_{4}\right)$ operated at 15 min spray interval. It was intended from the regression analysis that the $A_{1}$ and $A_{2}$ atomizers had a significant $(p<0.5)$ effect and $\mathrm{A}_{3}$ and $\mathrm{A}_{4}$ atomizers had a nonsignificant effect ( $p>0.05$ ) at $15 \mathrm{~min}, 30 \mathrm{~min}, 45 \mathrm{~min}$, and $60 \mathrm{~min}$ spray intervals on root length. The plants sprayed with the $A_{1}$ atomizers at different spray intervals appeared stocky compared to those sprayed with the $A_{2}, A_{3}$, and $A_{4}$ atomizers. However, the plants sprayed with the $\mathrm{A}_{4}$ atomizers were slender compared to those sprayed with the $A_{1}$, $A_{2}$ and $A_{3}$ atomizers at different spray intervals. For the average shoot length, an increasing trend was observed for the $A_{1}, A_{2}$, and $\mathrm{A}_{3}$ atomizers. The highest $(15.25 \mathrm{~cm})$ and lowest $(4.08 \mathrm{~cm})$ shoot lengths were calculated for $\mathrm{A}_{1} \mathrm{I}_{2}$ and $\mathrm{A}_{4} \mathrm{I}_{1}$ treatments. Accordingly, the regression analysis results of average shoot length indicated that the air-assisted atomizer $\left(\mathrm{A}_{1}\right)$ and air-less atomizer $\left(\mathrm{A}_{3}\right)$ had significant $(p<0.05)$ effects at $15,30,45$, and $60 \mathrm{~min}$ spray intervals. Furthermore, the average leaf area results indicated an increasing trend in $\mathrm{A}_{1}, \mathrm{~A}_{2}$, and $\mathrm{A}_{3}$ operated at the proposed spray intervals. However, a mixed increasing and decreasing trend was observed for the ultrasonic fogger at four different spray intervals. The highest leaf area of $56.59 \mathrm{~cm}^{2}$ was calculated in $\mathrm{A}_{1} \mathrm{I}_{2}$ treatment, and the lowest leaf area was measured in the ultrasonic fogger at 15 min spray interval $\left(\mathrm{A}_{4} \mathrm{I}_{1}\right)$. The regression analysis revealed that the air-assisted atomizer $\left(\mathrm{A}_{1}\right)$ and air-less $\left(\mathrm{A}_{2}\right.$ and $\left.\mathrm{A}_{3}\right)$ atomizers had significant $(p<0.05)$ effects and that the ultrasonic fogger had nonsignificant $(p>0.05)$ effects at $15 \mathrm{~min}, 30 \mathrm{~min}$, $45 \mathrm{~min}$, and $60 \mathrm{~min}$ spray intervals on the leaf area. The results of this experimental study contracted with the reported results of Tibbitts et al ${ }^{[32]}$. Chiipanthenga et al. ${ }^{[35]}$, Gao et al. ${ }^{[51]}$, Buckseth et al. ${ }^{[18]}$, Lakhiar et al.$^{[6]}$, Lakhiar et al. ${ }^{[52]}$, Tunio et al. ${ }^{[11]}$ concluded that leafy vegetables treated under droplet sizes were comparably different in morphological parameters with respect to spray interval in aeroponic systems.

3.2.2 Shoot and root fresh and dry weight (SFW, SDW, RFW, RDW)

Likewise, there was a significant $(p<0.05)$ difference in shoot and root (fresh \& dry weight in all treatments. It is well-known that the plant yield entirely depended on SFW. SFW and RFW 
were highest $(65.74 \mathrm{~g} /$ plant, and $14.37 \mathrm{~g} /$ plant $)$ in $\mathrm{A}_{1} \mathrm{I}_{2}$ treatment and the lowest (7.22 g/plant, and $1.92 \mathrm{~g} /$ plant) in $\mathrm{A}_{4} \mathrm{I}_{4}$, and $\mathrm{A}_{4} \mathrm{I}_{1}$ treatments, as shown in Figures $5 \mathrm{a}$ and $5 \mathrm{~b}$. However, the maximum $15.48 \%$ reduction in SDW after oven-dried was calculated in $\mathrm{A}_{4} \mathrm{I}_{2}$ treatment, and the minimum reduction of $3.25 \%$ was observed in $A_{1} I_{2}$ treatment (Figure $5 b$ ). The descending order for shoot fresh weight in all treatments was $A_{1}, A_{3}, A_{2}, A_{4}$ at $30 \mathrm{~min}, 45 \mathrm{~min}, 60 \mathrm{~min}, 15 \mathrm{~min}$ of spray intervals. The regression analysis results of shoot and root (fresh and dry) weight indicated that droplet size had a highly significant effect $(p<0.01)$ and that nutrient solution spray interval had a significant $(p<0.05)$ effect on SFW, RFW, SDW, and RDW. More importantly, Ultrasonic foggers had nonsignificant $(p>0.05)$ effects on SFW, RFW, SDW and RDW in all treatments. The interesting phenomenon of increasing and decreasing root and shoot biomass (fresh \& dry) under all atomizers with respect to spray interval was observed ${ }^{[53]}$. The greater root growth provided greater shoot biomass (yield) as compared to air-less and ultrasonic foggers misted at different spray intervals ${ }^{[42]}$. The present results coincide with the previously stated results that the yield of lettuce plants could be 50-150 g/plant ${ }^{[2]}$. Carrasco et al. ${ }^{[54]}$ reported the same type of results that droplet size affected the fresh weight, dry weight root to shoot ratio of lettuce plants. Another study by Coronel et al. ${ }^{[55]}$ concluded that interaction between droplet size and spraying interval could significantly affect the biomass but not the root shoot ratio.
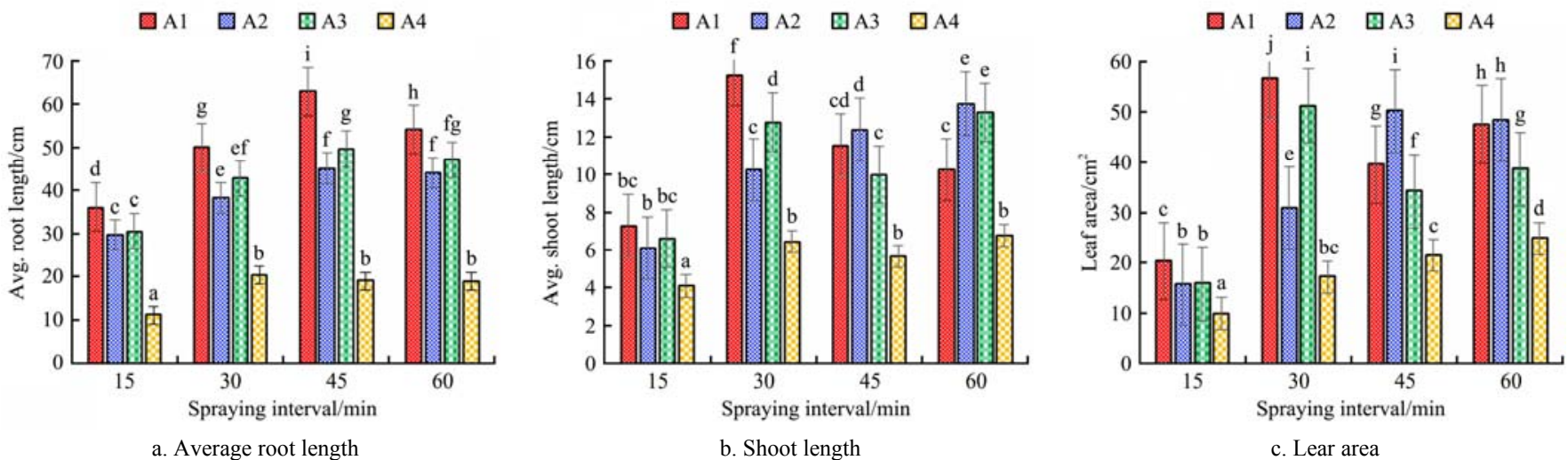

Note: Verticals bars are the mean $\pm \mathrm{SE}$; bars labeled with superscript letters are significantly different at $p<0.05$.

Figure 4 Average root length, shoot length, and leaf area observed in the lettuce grown in different atomizers operated at different nutrient solution spray intervals
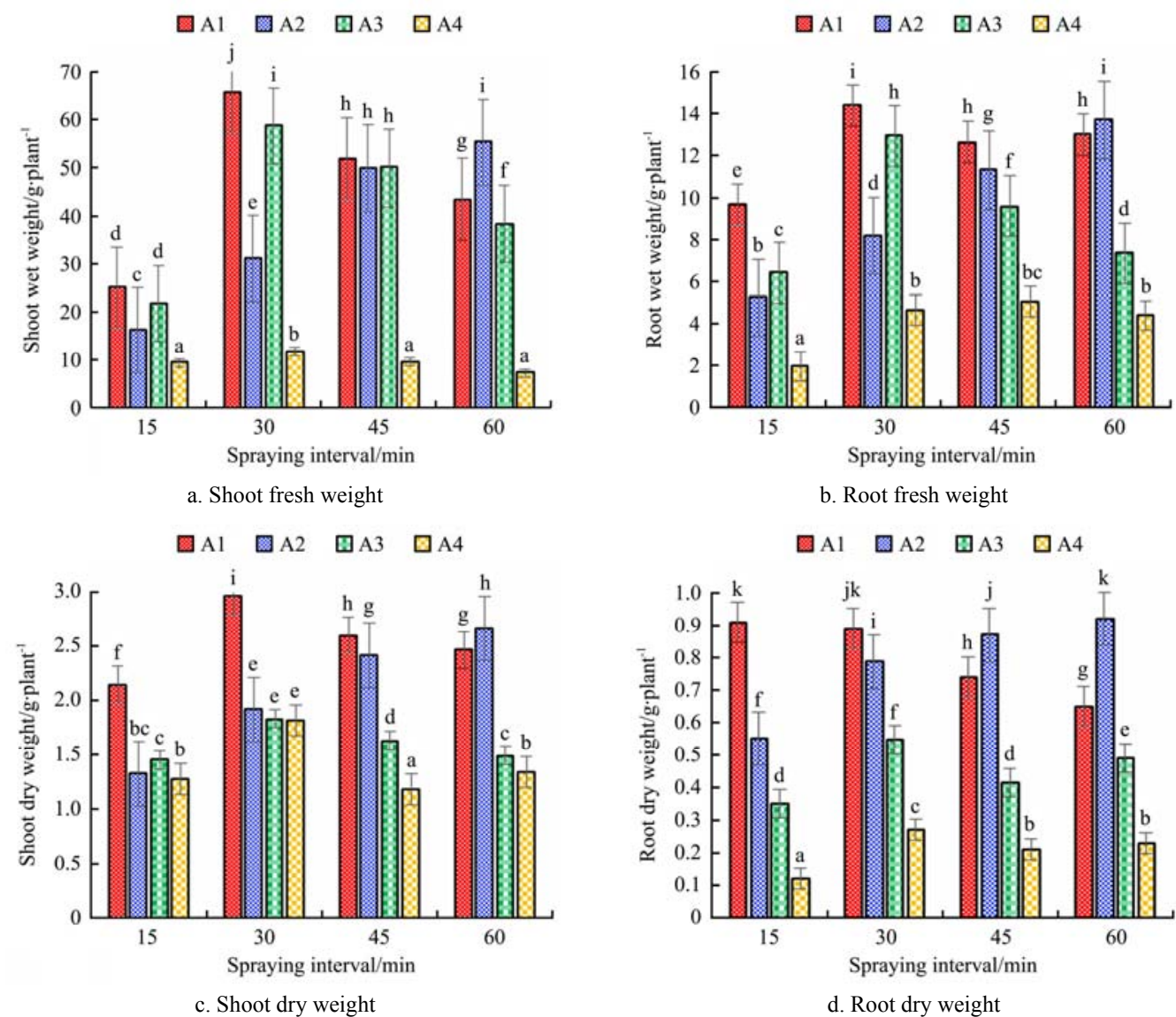

Note: Vertical bars are the mean $\pm \mathrm{SE}$; bars labeled with superscript letters are significantly different at $p<0.05$.

Figure 5 Shoot fresh weight, root fresh weight, shoot dry weight, and root dry weight observed for the lettuce grown in different atomizers operated at different nutrient solution spray intervals 


\subsubsection{Root-to-shoot ratio (Fresh \& Dry)}

The analyzed results of the root-to-shoot ratio on a fresh and dry basis are depicted in Figure 6. The most remarkable result for the root-to-shoot ratio was that the air-assisted atomizer at $15 \mathrm{~min}$ and 60 min spray intervals had the maximum root-to-shoot ratio (fresh). The results also revealed that the mixed phenomenon decreasing and increasing trend of root-to-shoot ratio (fresh and dry) occurred in $A_{1}$ and $A_{4}$ atomizers operated at $15 \mathrm{~min}, 30 \mathrm{~min}$, $45 \mathrm{~min}$, and 60 min spray intervals. Additionally, the $\mathrm{A}_{2}$ and $\mathrm{A}_{3}$ atomizers showed an increasing trend at proposed spray intervals. The regression analysis results for the root-to-shoot ratio (fresh and dry) indicated that only the $A_{1}$ had a significant $(p<0.05)$ effect on the root-to-shoot ratio (fresh and dry). The atomizers $\left(\mathrm{A}_{2}, \mathrm{~A}_{3}\right.$, and $\mathrm{A}_{4}$ ) at $15 \mathrm{~min}, 30 \mathrm{~min}, 45 \mathrm{~min}$, and $60 \mathrm{~min}$ spray intervals had nonsignificant $(p>0.05)$ effects on the root-to-shoot ratio (fresh and dry). The droplet sizes (atomizers) and spray intervals also affected the root-to-shoot ratio. Moreover, the results indicated that the weight of shoot weight was higher than that of root weight under all treatments which significantly differ the values of the root-to-shoot ratio ${ }^{[46]}$.

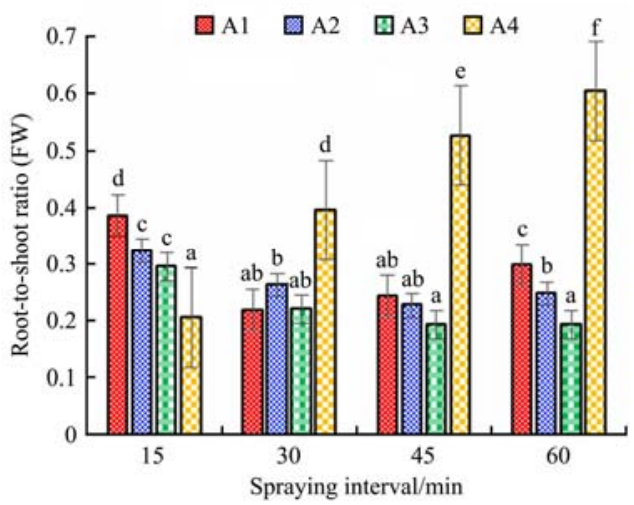

a. Root-to-shoot ratio (wet weight)

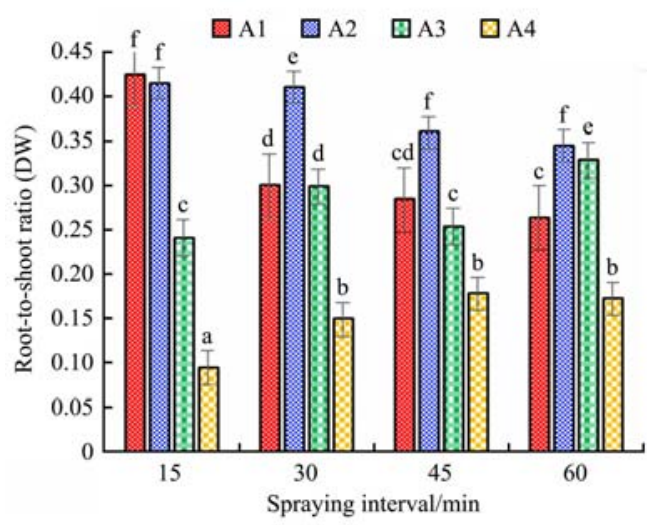

b. Root-to-shoot ratio (dry weight)

Note: Vertical bars are the mean $\pm \mathrm{SE}$; bars labeled with superscript letters are significantly different at $p<0.05$.

Figure 6 Root-to-shoot ratio (wet weight) and root-to-shoot ratio (dry weight) observed in the lettuce grown in different atomizers operated at different nutrient solution spray intervals

\subsection{The response of photosynthetic characteristics}

As shown in Figure 7a, the atomizer type had a significant positive effect and a strong interaction with spray interval on the net photosynthesis rate (Pn) of lettuce. The highest photosynthesis rate $\left(12.98 \mu \mathrm{mol} \mathrm{CO} / \mathrm{m}^{2} \cdot \mathrm{s}\right)$ was observed in $\mathrm{A}_{1} \mathrm{I}_{2}$ treatment. However, the lowest photosynthesis rate $(7.25 \mu \mathrm{mol}$ $\mathrm{CO}_{2} / \mathrm{m}^{2} \cdot \mathrm{s}$ ) was observed in the ultrasonic fogger at 15 min spray interval $\left(\mathrm{A}_{4} \mathrm{I}_{1}\right)$. Overall, our data demonstrate that the air-assisted atomizer at different spray intervals presented higher values of $\mathrm{Pn}$ than $\mathrm{A}_{2}, \mathrm{~A}_{3}$, and $\mathrm{A}_{4}$ atomizers at $15 \mathrm{~min}, 30 \mathrm{~min}, 45 \mathrm{~min}$, and 60 min spray intervals.

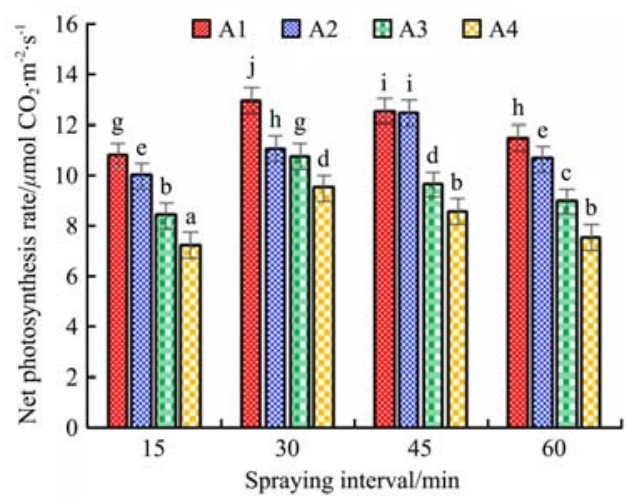

a. Net photosynthesis rate

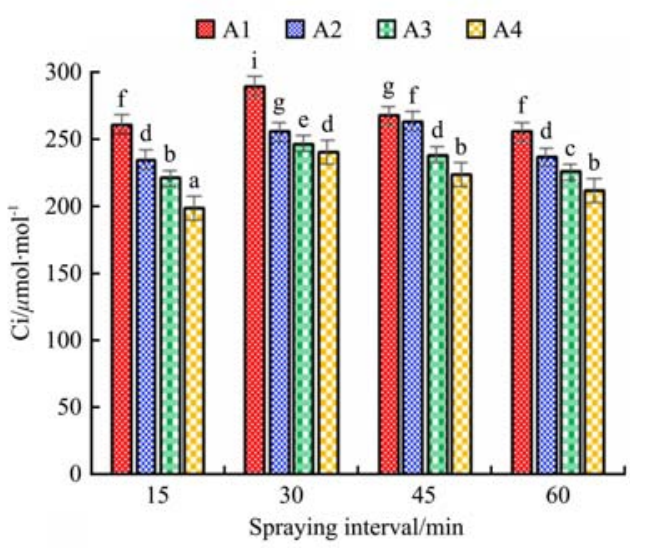

b. Intercellular $\mathrm{CO} 2$ concentration

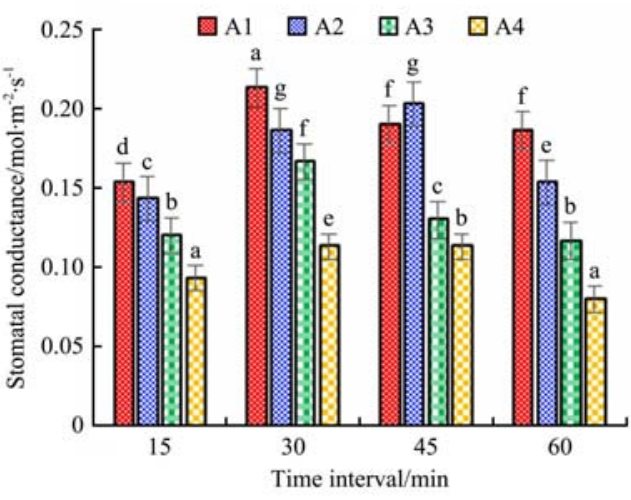

c. Stromal conductance

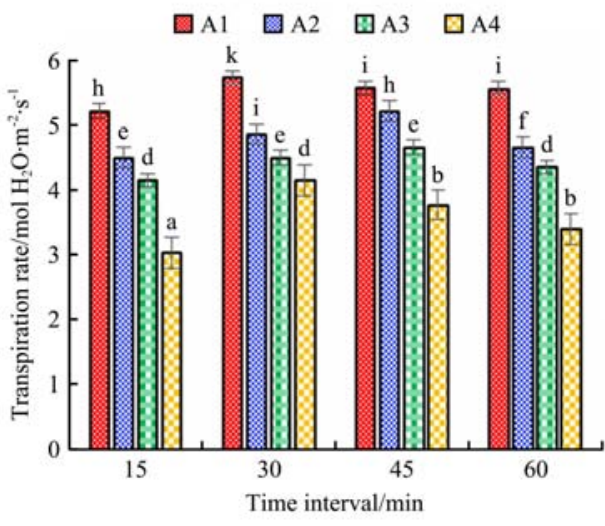

d. Transpiration rate

Note: Vertical bars are the mean $\pm \mathrm{SE}$; bars labeled with superscript letters are significantly different at $p<0.05$.

Figure 7 Net photosynthesis rate, intercellular $\mathrm{CO}_{2}$ concentration, stromal conductance, and transpiration rate in the lettuce grown in different atomizers operated at different time intervals 
The experimental results of intercellular $\mathrm{CO}_{2}$ concentration $(\mathrm{Ci})$ are depicted in Figure $7 \mathrm{~b}$. Different atomizers at different spray intervals had significantly $(p<0.05)$ different $\mathrm{Ci}$ values. The droplet size (atomizer) without air was directly proportional to the $\mathrm{Ci}$ value. In general, the $\mathrm{Ci}$ values decreased more in the ultrasonic fogger at $15 \mathrm{~min}, 30 \mathrm{~min}, 45 \mathrm{~min}$, and $60 \mathrm{~min}$ spray intervals. The minimum reduction was observed in air-assisted atomizers operated at $30 \mathrm{~min}$ and $45 \mathrm{~min}$ spray intervals. Furthermore, the air-assisted atomizers showed a moderate reduction when spray at $15 \mathrm{~min}$ and 60 min spray intervals.

In general, the stromal conductance (Gs) and transpiration rate (Eleaf) indicated parallel changes with Pn in different combinations of atomizers and spray intervals (Figures $7 \mathrm{c}$ and $7 \mathrm{~d}$ ). Similar to $\mathrm{Pn}$, they showed a positive correlation in all treatments. More importantly, in all treatments, the Gs values significantly $(p<0.05)$ increased at the $30 \mathrm{~min}$ and $45 \mathrm{~min}$ spray intervals. For the Eleaf, the maximum values of $5.72 \mathrm{~mol} \mathrm{H} \mathrm{H}_{2} \mathrm{O} / \mathrm{m}^{2} \cdot \mathrm{s}$ were observed for the A1 atomizer at 30 min spray intervals.

The regression analysis results for $\mathrm{Pn}, \mathrm{Ci}$, Gs, and Eleaf indicated that $\mathrm{A}_{1}$ and $\mathrm{A}_{3}$ had significant $(p<0.05)$ effects on Pn and that $\mathrm{A}_{1}$ and $\mathrm{A}_{2}$ had significant $(p<0.05)$ effects on $\mathrm{Ci}$ and Eleaf; however, only $A_{1}$ had a significant $(p<0.05)$ effect on Gs at 15 min, $30 \mathrm{~min}, 45 \mathrm{~min}$, and $60 \mathrm{~min}$ spray intervals. The results also reveal that the air-assisted atomizer had a highly significant ( $p \leq$ 0.01 ) effect on $\mathrm{Pn}, \mathrm{Ci}$, and $\mathrm{Gs}$, while the ultrasonic fogger had a nonsignificant $(p>0.05)$ effect on all parameters at proposed nutrient solution spray intervals. These results revealed that the leaf net photosynthesis rate of lettuce increased with increasing oxygen availability in the root zone chamber ${ }^{[5]}$. The benefit of a suitable droplet size (atomizer) with respect to the proper nutrient solution spray interval on plant growth largely results from increased plant photosynthesis ${ }^{[56,57]}$. Ougham et al. ${ }^{[58]}$ reported
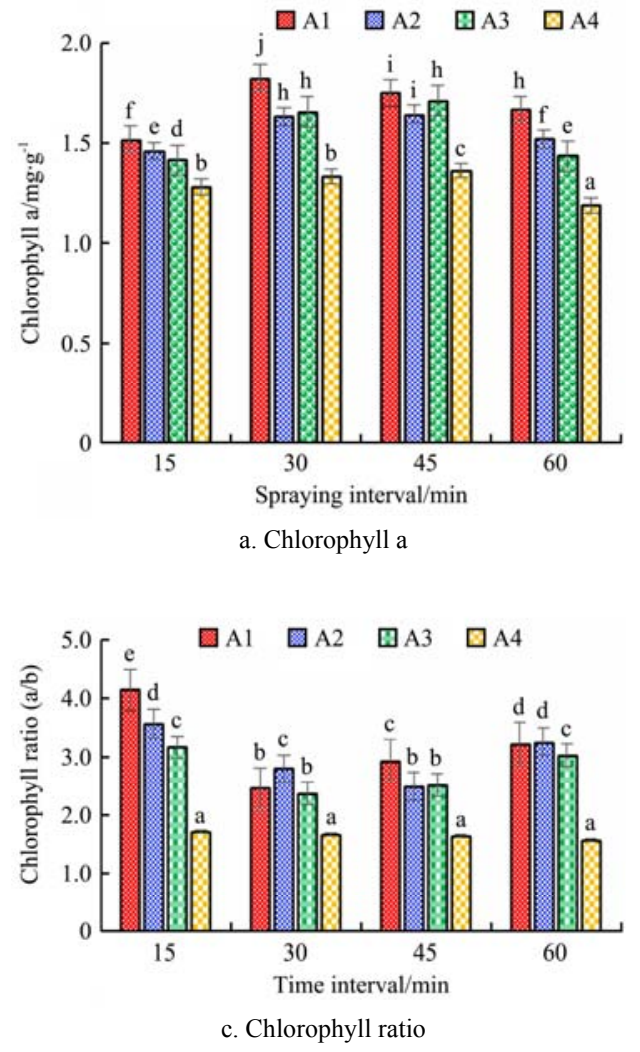

similar results, showing that stomatal conductance was correlated with Pn. These results also agreed that droplet size at proper nutrient solution spray intervals increases the Eleaf of plants by increasing the Gs and temperature of the leaf ${ }^{[59,60]}$.

\subsection{Photosynthetic pigments}

The interaction of nutrient solution spray intervals and atomizers (droplet size) had a significant $(p<0.05)$ effect on photosynthetic pigments. In figure 8 , it can be seen that highest levels of chlorophyll a $(1.83 \mathrm{mg} / \mathrm{g})$ and chlorophyll b $(0.83 \mathrm{mg} / \mathrm{g})$ were calculated in $\mathrm{A}_{1} \mathrm{I}_{2}$ and $\mathrm{A}_{4} \mathrm{I}_{3}$ treatments. The $\mathrm{A}_{1}$ atomizers at different spray intervals had high advantages from the initial to the final stage, and ultrasonic foggers had a lower level during the entire life cycle. The lowest concentrations of chlorophyll a $(1.19 \mathrm{mg} / \mathrm{g})$ and chlorophyll $\mathrm{b}(0.37 \mathrm{mg} / \mathrm{g})$ were achieved in $\mathrm{A}_{4} \mathrm{I}_{4}$ and $A_{1} I_{1}$ treatments, respectively. Furthermore, the value added to chlorophyll a was greater than that of chlorophyll $b$ for all treatments; thus, the chlorophyll $\mathrm{a} / \mathrm{b}$ increased. Moreover, the concentration of carotenoids responded in a highly significant fashion $(p<0.001)$ with different atomizers (droplet sizes), and the four spray intervals had significant $(p<0.05)$ effects. Additionally, the interactions of $\mathrm{A}_{1}, \mathrm{~A}_{2}$ and $\mathrm{A}_{3}$ had a significant $(p<0.05)$ effect on the concentration of carotenoids at 30 and 45 min spray intervals but not at the $15 \mathrm{~min}$, and $60 \mathrm{~min}$ spray intervals. The highest and lowest carotenoid values of $0.21 \mathrm{mg} / \mathrm{g}$ and $0.04 \mathrm{mg} / \mathrm{g}$ were observed in $\mathrm{A}_{4} \mathrm{I}_{1}$ and $\mathrm{A}_{1} \mathrm{I}_{2}$ treatments, respectively. The concentration of carotenoids first increased at the 15 min spray interval, then decreased at the 30 and 45 min intervals, and again increased at the $60 \mathrm{~min}$ interval in $\mathrm{A}_{1}, \mathrm{~A}_{2}, \mathrm{~A}_{3}$, and $\mathrm{A}_{4}$. It was observed from the regression analysis results that the $A_{1}$ atomizer had a significant $(p<0.05)$ effect on chlorophyll a, b and carotenoids; moreover, $\mathrm{A}_{2}$ showed significant $(p<0.05)$ effects on chlorophyll a and carotenoids, while $\mathrm{A}_{3}$ had a significant $(p<0.05)$
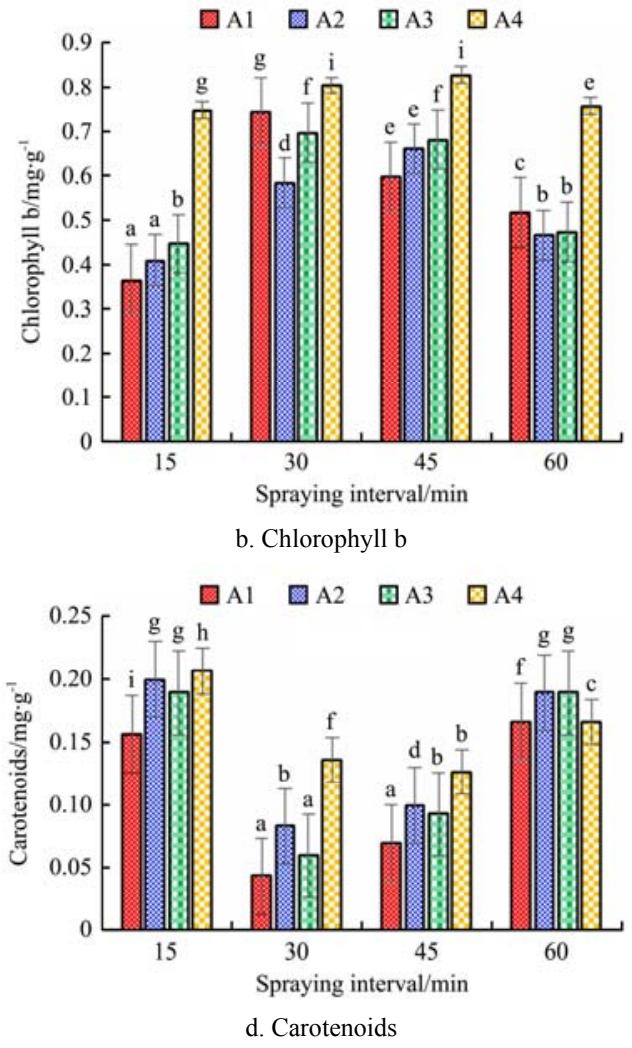

Note: Vertical bars are the mean $\pm \mathrm{SE}$; bars labeled with superscript letters are significantly different at $p<0.05$.

Figure 8 Chlorophyll a, chlorophyll b, chlorophyll ratio, and carotenoids in the lettuce grown in different atomizers at different time intervals 
effect only on chlorophyll a. Likewise, the $\mathrm{A}_{4}$ atomizer had nonsignificant $(p>0.05)$ effects on all measured parameters. These research findings support the previous studies that proper droplet size and spray nutrient solutions could increase the chlorophyll content in the leaves ${ }^{[41]}$. It was also observed that under $\mathrm{A}_{4}$ atomizer at four nutrient solution spray intervals, the concentration of chlorophyll was very low; this phenomenon reduced the photosynthesis efficiency and resulted in a very small growth of shoot and root ${ }^{[61]}$. Furthermore, it can be seen in Figure $8 \mathrm{c}$ that the carotenoids reacted positively to droplet size at spray intervals. The concentration of carotenoids increased firstly at spray intervals of $15 \mathrm{~min}$, then decreased at $30 \mathrm{~min}$ and $45 \mathrm{~min}$ and again increased at 60 min under $A_{1}, A_{2}, A_{3}$ and $A_{4}{ }^{[43,50]}$. The carotenoid content was positively associated with the interaction of droplet sizes and spray intervals ${ }^{[62]}$. Similar to the results of this study, the positive effects of droplet sizes and spray intervals were reported in kale $\mathrm{e}^{[63]}$.

\subsection{Nutritional quality of lettuce}

As seen in Figure 9, the nitrate concentration of lettuce leaves significantly responded to the atomizer type (droplet size), nutrient solution spray interval and their interaction $(p<0.05)$. The maximum and minimum nitrate contents of $85.38 \mathrm{~g} / \mathrm{kg}$ and $3.08 \mathrm{~g} / \mathrm{kg}$ were observed for $\mathrm{A}_{1} \mathrm{I}_{2}$ and $\mathrm{A}_{4} \mathrm{I}_{1}$ treatment, respectively. Moreover, vitamin $\mathrm{C}$ is parabolically correlated with nutrient solution spray intervals. The results revealed that the highest

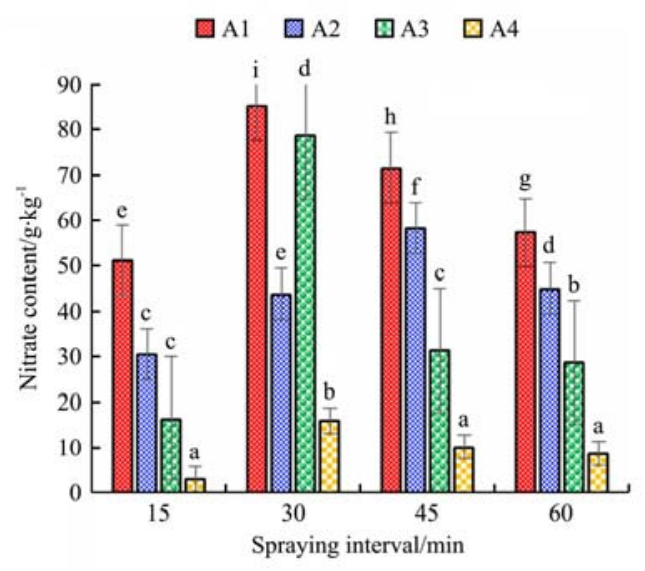

a. Nitrate content

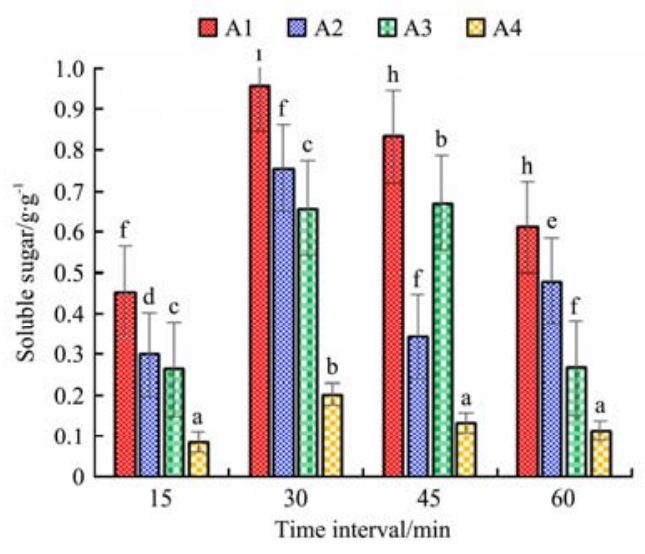

c. Soluble sugar content vitamin $\mathrm{C}$ content was observed at the 30 min spray interval for the A1 atomizer at $0.36 \mathrm{~g} / \mathrm{kg}$ and that the lowest was observed for $\mathrm{A}_{4} \mathrm{I}_{4}$. Furthermore, the highly significant $(p<0.001)$ effect of droplet size was illustrated for soluble sugar and soluble protein. The $A_{1}$ atomizer at 45 min spray intervals had higher values than $A_{2}$, and $\mathrm{A}_{3}$ atomizers at proposed spray intervals. Furthermore, A4 had nonsignificant $(p<0.05)$ effects on nitrate, vitamin $\mathrm{C}$, soluble sugar and protein. The regression analysis results indicated that the air-assisted atomizer operated at 15,30, 45 and $60 \mathrm{~min}$ spray intervals had significant $(p<0.05)$ effects on nitrate, vitamin $\mathrm{C}$, soluble sugar and protein. The air-less atomizer (A2) had a significant $(p<0.05)$ effect only on soluble sugar, and the A3 atomizer had significant $(p<0.05)$ effects on nitrate and vitamin $\mathrm{C}$ contents. The air-assisted atomizers at $30 \mathrm{~min}$ of spray interval were the most suitable atomizer for the nutritional quality of lettuce ${ }^{[53]}$. These results coincided with previous results showing that the proper droplet size provides more carbohydrate and photochemical energy to speed up nitrate accumulation ${ }^{[64]}$. The results also revealed that the soluble sugar and protein was low at $15 \mathrm{~min}$ of spray interval, it was maximum at $30 \mathrm{~min}$ of spray interval and then decreased with increasing the spray intervals under all atomizers ${ }^{[65,66]}$. The finding of this study concluded that a combination of air-assisted atomizers and $30 \mathrm{~min}$ of spray interval could be beneficial to improve the nutritional quality of lettuce.

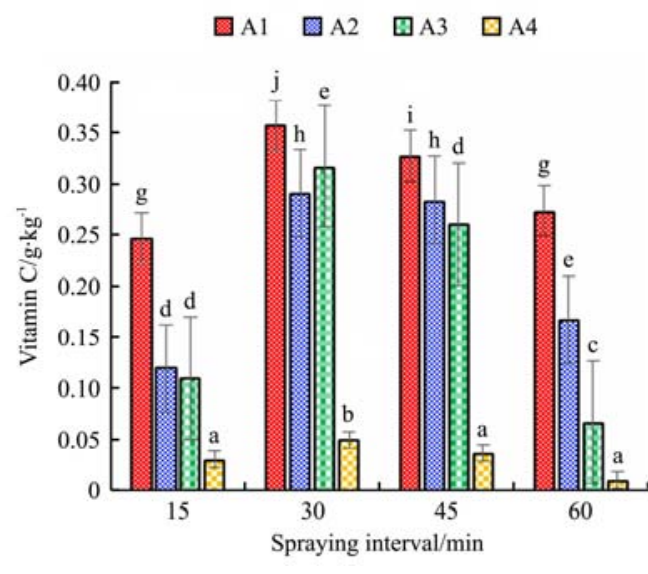

b. Vitamin $\mathrm{C}$ content

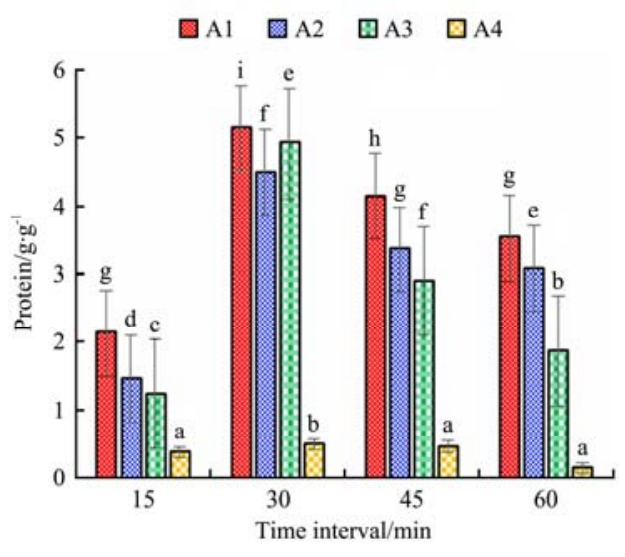

d. Protein content

Note: Vertical bars are the mean $\pm \mathrm{SE}$; bars labeled with superscript letters are significantly different at $p<0.05$.

Figure 9 Nitrate content, vitamin C content, soluble sugar content, and protein in lettuce leaves grown in different atomizers at different time intervals

\section{Conclusions}

In this study, it was observed that the use of air-assisted atomizers $\left(\mathrm{A}_{1}\right)$ operated at a 30 min nutrient solution spray interval is more suitable than the use of air-less atomizers $\left(A_{2}\right.$ and $\left.A_{3}\right)$ for the growth, photosynthesis characteristics, pigments, and 
nutritional quality of aeroponically grown lettuce. The results also revealed that ultrasonic foggers $\left(\mathrm{A}_{4}\right)$ operated at $15 \mathrm{~min}$, $30 \mathrm{~min}, 45 \mathrm{~min}$, and $60 \mathrm{~min}$ nutrient solution spray intervals are not suitable for lettuce plants cultivated in aeroponics systems. The combination of $A_{1}$ and $I_{2}$ treatment significantly improved the photosynthesis, and the root characteristics resulted in the increased shoot biomass (yield) and nutritional quality of lettuce leaves when using Hoagland's nutrient solution. However, the reduction in shoot biomass (yield), photosynthesis efficiency, and nutritional quality of lettuce in ultrasonic foggers at spray interval require further investigation in aeroponic systems. Additionally, long-term studies on droplet size and spray intervals of leafy vegetables in aeroponics systems are fully encouraged to conform statements and present data.

\section{Acknowledgements}

The authors acknowledged that this work was financially supported by the National Natural Science Foundation of China Program (Grant No. 51975255), Jiangsu Agriculture Science and Technology Innovation Funds (JASTIF), (Grant No. CX (18) 3048), and the "Project Funded by the Priority Academic Program Development of Jiangsu Higher Education Institutions (No. 37, 2014).

\section{[References]}

[1] Tunio M H, Gao J, Talpur M A, Lakhiar I A, Chandio F A, Shaikh S A, et al. Effects of different irrigation frequencies and incorporation of rice straw on yield and water productivity of wheat crop. Int J Agric \& Biol Eng, 2020; 13(1): 138-145.

[2] Khan S, Yu H, Li Q, Gao Y, Sallam B N, Wang H, et al. Exogenous application of amino acids improves the growth and yield of lettuce by enhancing photosynthetic assimilation and nutrient availability. Agronomy, 2019; 9(5): 266-282.

[3] Michelon N, Pennisi G, Myint N O, Dall'Olio G, Batista L P, Salviano AAC, et al. Strategies for improved yield and water use efficiency of lettuce (Lactuca sativa L.) through simplified soilless cultivation under semi-arid climate. Agronomy, 2020; 10(9): 1379-1392.

[4] Gruda N, Bisbis M, Tanny J. Impacts of protected vegetable cultivation on climate change and adaptation strategies for cleaner production-a review. Journal of Cleaner Production, 2019; 225: 324-339.

[5] Asaduzzaman M, Saifullah M, Mollick A S R, Hossain M M, Halim G, Asao T. Influence of soilless culture substrate on improvement of yield and produce quality of horticultural crops. Soilless Culture-Use of Substrates for the Production of Quality Horticultural Crops, 2015; 10: 400-413.

[6] Lakhiar I A, Gao J, Syed T N, Chandio F A, Buttar N A. Modern plant cultivation technologies in agriculture under controlled environment: A review on aeroponics. Journal of Plant Interactions, 2018; 13(1): 338-352.

[7] Lakhiar I A, Gao J, Xu X, Syed T N, Chandio F A, Jing Z, et al. Effects of various aeroponic atomizers (droplet sizes) on the growth, total polyphenol content and antioxidant activity of leafy lettuce (Lactuca sativa L.). Transactions of the ASABE, 2019; 62(6): 1475-1487.

[8] Lakhiar I A, Jianmin G, Syed T N, Chandio F A, Buttar N A, Qureshi W A. Monitoring and control systems in agriculture using intelligent sensor techniques: A review of the aeroponic system. Journal of Sensors, 2018; 18: 8672769 . doi: $10.1155 / 2018 / 8672769$

[9] Jones Jr J B. Hydroponics: its history and use in plant nutrition studies. Journal of plant Nutrition, 1982; 5(8): 1003-1030.

[10] Lal R. Feeding 11 billion on 0.5 billion hectare of area under cereal crops. Food and Energy Security, 2016; 5(4): 239-251.

[11] Tunio M H, Gao J, Shaikh S A, Lakhiar I A, Qureshi W A, Solangi K A, et al. Potato production in aeroponics: An emerging food growing system in sustainable agriculture forfood security. Chilean Journal of Agricultural Research, 2020; 80(1): 118-132.

[12] Zimmerman P W, Went F W. The experimental control of plant growth. Bulletin of the Torrey Botanical Club, 1958; 85(4): 274-275.
[13] Nichols M A, Christie C B. Continuous production of greenhouse crops using aeroponics. Acta Horticulturae, 2002; 578: 289-291.

[14] Stoner R, Clawson J. A high performance, gravity insensitive, enclosed aeroponic system for food production in space. Principal Investigator, 1998; NASA SBIR NAS10-98030.

[15] Giacomelli G, Smith S. Fog for aeroponic plant production. Soilless culture, 1989; 5(1): 13-22.

[16] Weathers P J, Zobel R W. Aeroponics for the culture of organisms, tissues and cells. Biotechnology advances, 1992; 10(1): 93-115.

[17] Repetto A, Cadinu M, Leoni S. The effect of plant position on root development and vegetative growth in aeroponic lettuce. Acta Horticulturae, 1993; 361: 603-611.

[18] Buckseth T, Sharma A, Pandey K, Singh B, Muthuraj R. Methods of pre-basic seed potato production with special reference to aeroponics-A review. Scientia Horticulturae, 2016; 204: 79-87.

[19] Demšar J, Osvald J, Vodnik D. The effect of light-dependent application of nitrate on the growth of aeroponically grown lettuce (Lactuca sativa L.). Journal of the American Society for Horticultural Science 2004; 129(4): 570-575.

[20] Lim M. Trials with aeroponics for the cultivation of leafy vegetables. Proceedings of the 9th International Congress on Soilless Culture, 1996; pp.265-272.

[21] Farran I, Mingo-Castel A M. Potato minituber production using aeroponics: effect of plant density and harvesting intervals. American Journal of Potato Research, 2006; 83(1): 47-53.

[22] Ritter E, Angulo B, Riga P, Herran C, Relloso J, San Jose M. Comparison of hydroponic and aeroponic cultivation systems for the production of potato minitubers. Potato Research, 2001; 44(2): 127-135.

[23] Christie C B, Nichols M A. Aeroponics-A production system and research tool. Acta Horticulturae, 2004; 648: 185-190.

[24] Hayden A L. Aeroponic and hydroponic systems for medicinal herb, rhizome, and root crops. HortScience, 2006; 41(3): 536-538.

[25] de Kreij C, van der Hoeven B. Effect of humic substances, $\mathrm{pH}$ and its control on growth of chrysanthemum in aeroponics. Proceedings of the 9th International Congress on Soilless Culture, 1997; pp.207-230.

[26] Fascella G, Zizzo G. Preliminary results of aeroponic cultivation of anthurium andreanum for cut flower production. Acta Horticulturae, 2007; 747: 233-240

[27] Martin-Laurent F, Tham F-Y, Lee S-K, He J, Diem HG. Field assessment of aeroponically grown and nodulated Acacia mangium. Australian Journal of Botany, 2000; 48(1): 109-114.

[28] Barak P, Smith J, Krueger A, Peterson L. Measurement of short-term nutrient uptake rates in cranberry by aeroponics. Plant, Cell \& Environment, 1996; 19(2): 237-242.

[29] Tunio M H, Gao J, Lakhiar I A, Solangi K A, Qureshi W A, Shaikh S A, et al. Influence of atomization nozzles and spraying intervals on growth, biomass yield, and nutrient uptake of butter-head lettuce under aeroponics system. Agronomy, 2021; 11(1): 97-113.

[30] Lakhiar I A, Gao J, Syed T N, Chandio F A, Tunio M H, Ahmad F, et al. Overview of the aeroponic agriculture-An emerging technology for global food security. International Journal of Agricultural and Biological Engineering, 2020; 13(1): 1-10.

[31] Raring D. Aeroponic growing apparatus and method. United States patent application US 12/834,243. 2011, Feb 3.

[32] Tibbitts T W, Cao W. Solid matrix and liquid culture procedures for growth of potatoes. Advances in Space Research, 1994; 14(11): 427-433.

[33] Chohura P, Komosa A, Kołota E. Wpływ pH pożywek na dynamikę zawartości makroelementów w liściach pomidora szklarniowego uprawianego na wełnie mineralnej. Rocz AR Pozn CCCLVI, Ogrodn, 2004; 37: 29-35.

[34] Amoozgar A, Mohammadi A, Sabzalian M. Impact of light-emitting diode irradiation on photosynthesis, phytochemical composition and mineral element content of lettuce cv. Grizzly. Photosynthetica 2017; 55(1): 85-95.

[35] Chiipanthenga M, Maliro M, Demo P, Njoloma J. Potential of aeroponics system in the production of quality potato (Solanum tuberosum 1.) seed in developing countries. African Journal of Biotechnology 2012; 11(17): 3993-3999.

[36] Samuolienè G, Urbonavičiūtė A, Duchovskis P, Bliznikas Z, Vitta P, Žukauskas A. Decrease in nitrate concentration in leafy vegetables under a solid-state illuminator. HortScience, 2009; 44(7): 1857-1860.

[37] Son K-H, Oh M-M. Leaf shape, growth, and antioxidant phenolic 
compounds of two lettuce cultivars grown under various combinations of blue and red light-emitting diodes. HortScience, 2013; 48(8): 988-995.

[38] Gao J M, Ma J L. Design and test of low-frequency Hartmann atomization nozzle with stepped resonance tube. Transactions of the CSAE, 2017; 33(12): 66-73. (in Chinese)

[39] Signore A, Serio F, Santamaria P. A targeted management of the nutrient solution in a soilless tomato crop according to plant needs. Frontiers in Plant Science, 2016; 7: 391. doi: 10.3389/fpls.2016.00391.

[40] Erel R, T Le T, Eshel A, Cohen S, Offenbach R, Strijker T, et al. Root development of bell pepper (Capsicum annuum L.) as affected by water salinity and sink strength. Plants, 2020; 9(1): 35-44.

[41] Fu Y, Li L, Xie B, Dong C, Wang M, Jia B, et al. How to establish a Bioregenerative Life Support System for long-term crewed missions to the Moon or Mars. Astrobiology, 2016; 16(12): 925-936.

[42] Li Q, Li X, Tang B, Gu M. Growth responses and root characteristics of lettuce grown in aeroponics, hydroponics, and substrate culture. Horticulturae, 2018; 4(4): 35-43.

[43] Sun Y, Lin X, Jin C, Zhang Y, Fang P. Effects of nitrogen forms on ascorbate contents and metabolism in spinach (Spinacia oleracea L.). Journal of Zhejiang University (Agriculture and Life Sciences), 2009; 35(3): 292-298.

[44] Li H, Tang C, Xu Z. The effects of different light qualities on rapeseed (Brassica napus L.) plantlet growth and morphogenesis in vitro. Scientia Horticulturae, 2013; 150: 117-124

[45] Lichtenthaler H K, Wellburn A R. Determinations of total carotenoids and chlorophylls $\mathrm{a}$ and $\mathrm{b}$ of leaf extracts in different solvents. Biochemical Society Transactions, 1983; 11: 591-592

[46] Shi D, Zheng X, Li L, Lin W, Xie W, Yang J, et al. Chlorophyll deficiency in the maize elongated mesocotyl 2 mutant is caused by a defective heme oxygenase and delaying grana stacking. PloS One, 2013; 8(11): 80-107.

[47] Shyamala B, Jamuna P. Nutritional content and antioxidant properties of pulp waste from Daucus carota and Beta vulgaris. Malaysian journal of nutrition, 2010; 16(3): 397-408.

[48] Cataldo D, Maroon M, Schrader L, Youngs V. Rapid colorimetric determination of nitrate in plant tissue by nitration of salicylic acid. Communications in Soil Science and Plant Analysis, 1975; 6(1): 71-80.

[49] Bradford MM. A rapid and sensitive method for the quantitation of microgram quantities of protein utilizing the principle of protein-dye binding. Analytical biochemistry, 1976; 72(1-2): 248-254.

[50] Song S W, Yi L Y, Liu H C, Sun G W, Chen R Y. Effect of ammonium and nitrate ratio on nutritional quality of flowering Chinese cabbage. Applied Mechanics and Materials, 2012; 142: 188-192.

[51] Gao J, Zhang J, Lu D. Design and atomization experiments of an ultrasonic atomizer with a levitation mechanism. Applied Engineering in Agriculture, 2016; 32(4): 353-360.

[52] Lakhiar I A, Gao J, Xu X, Syed T N, Chandio F A, Jing Z, et al. Effects of various aeroponic atomizers (droplet sizes) on growth, polyphenol content, and antioxidant activity of leaf lettuce (Lactuca sativa L.) Transactions of the ASABE, 2019; 62(6): 1475-1487.

[53] Chen X, Guo W, Xue X, Wang L, Qiao X. Growth and quality responses of 'Green Oak Leaf'lettuce as affected by monochromic or mixed radiation provided by fluorescent lamp (FL) and light-emitting diode (LED). Scientia Horticulturae, 2014; 172: 168-175.

[54] Carrasco G, Tapia J, Urrestarazu M. Nitrate content in lettuces grown in hydroponic systems. Idesia, 2006; 24: 25-30.

[55] Coronel G, Chang M, Rodríguez-Delfín A. Nitrate reductase activity and chlorophyll content in lettuce plants grown hydroponically and organically. Acta Horticulturae, 2009; 843: 137-144.

[56] Cechin I, de Fátima Fumis T. Effect of nitrogen supply on growth and photosynthesis of sunflower plants grown in the greenhouse. Plant Science 2004;166(5): 1379-1385.

[57] Wu R L, Wang Y. Psychosocial interaction during a 105-day isolated mission in Lunar Palace 1. Acta Astronautica, 2015; 113: 1-7.

[58] Ougham H, Hörtensteiner S, Armstead I, Donnison I, King I, Thomas H, et al. The control of chlorophyll catabolism and the status of yellowing as a biomarker of leaf senescence. Plant Biology 2008; 10: 4-14.

[59] Leakey A D, Ainsworth E A, Bernacchi C J, Rogers A, Long S P, Ort D R. Elevated $\mathrm{CO}_{2}$ effects on plant carbon, nitrogen, and water relations: six important lessons from FACE. Journal of Experimental Botany, 2009; 60(10): 2859-2876.

[60] Sinha R K. Modern plant physiology. CRC Press, 2004; 500p.

[61] Hogewoning S W, Trouwborst G, Maljaars H, Poorter H, van Ieperen W, Harbinson J. Blue light dose-responses of leaf photosynthesis, morphology, and chemical composition of Cucumis sativus grown under different combinations of red and blue light. Journal of Experimental Botany, 2010; 61(11): 3107-3117.

[62] Lin K-H, Huang M-Y, Huang W-D, Hsu M-H, Yang Z-W, Yang C-M. The effects of red, blue, and white light-emitting diodes on the growth, development, and edible quality of hydroponically grown lettuce (Lactuca sativa L. var. capitata). Scientia Horticulturae, 2013; 150: 86-91.

[63] Pavlou G C, Ehaliotis C D, Kavvadias V A. Effect of organic and inorganic fertilizers applied during successive crop seasons on growth and nitrate accumulation in lettuce. Scientia Horticulturae, 2007; 111(4): 319-325.

[64] Qi H, Li T, Liu H, Zhang J. Studies on carbohydrate content and sucrose metabolizing enzymes activities in different parts of tomato. Acta Hort Sinica, 2005; 32: 239-243.

[65] Gao J M, Hussian Tunio M, Chen Y M, He R. Design and experiment of low-frequency ultrasonic nozzle integrating air-assistant system and acoustic levitation mechanism. Int J Agric \& Biol Eng, 2020; 13(6): 25-33.

[66] Zhang D P, Zhang T Y, Ji J W, Sun Z P, Wang Y G, Sun Y T, et al. Estimation of solar radiation for tomato water requirement calculation in Chinese-style solar greenhouses based on least mean squares filter. Sensors, 2020; 20(1): 155. doi: 10.3390/s20010155. 